\title{
GPR54 is a target for suppression of metastasis in endometrial cancer( Abstract_要旨 )
}

\section{AUTHOR(S):}

Kang, Hyun Sook

\section{CITATION:}

Kang, Hyun Sook. GPR54 is a target for suppression of metastasis in endometrial cancer. 京都大学, 2011, 博士(医学)

ISSUE DATE:

2011-05-23

URL:

http://hdl.handle.net/2433/142549

RIGHT: 


\begin{tabular}{|l|l|c|c|}
\hline 京都大学 & 博士（医 学 ） & 氏 名 & 姜 賢 淑 \\
\hline 論文題目 & $\begin{array}{c}\text { GPR54 is a target for suppression of metastasis in endometrial cancer } \\
\text { (子宮体癌における GPR54 の発現は、転移を抑制する方向に働く） }\end{array}$ \\
\hline
\end{tabular}

（論文内容の要旨）

子宮体癌は、我が国において新規患者数が年間約 8000 人と婦人科悪性腫場のなかで最多であり、 この 10 年間で倍増している。子宮体癌は、その多くが高分化型で子宮に限局し、おおむね教後良 好であるものの、低分化型のものは子宮外一活発に進展し、転移や再発を起こしやすい。子宮体癌 の転移はリンパ節転移の頻度が高く、このような症例の予後は不良である。リンパ節転移と相関す る危険因子として深部子宮筋層浸潤・リン八゚管侵襲があり、癌細胞が子宮体部筋層 $1 / 2$ を越えて浸 潤した場合のリンパ節転移の頻度は $26 \%$ と、1/2 以下の場合の $6 \%$ に対し、高くなることが知られ ている。近年、転移抑制遺伝子 KISSI の遺伝子産物であるメタスチンが癌細胞の浸潤能・転移能 を抑制することが注目されている。そこで本研究では、子宮体癌における発現と局所浸潤およびリ ンパ節転移との関係に着目した。

メタスチンは、膜貫通型の細胞膜受容体である GPR54 に結合し細胞内にシグナルを伝える。 metastin-10 やFTM080 は各々アミノ酸 10 残基、5 残基からなる低分子ペプチドでいずれも強い メタスチン活性を持つ。これまでに他癌種において GPR54 とメタスチンの発現について幾つか報 告がなされているが、その結果は癌種によって異なり、転移への関与だけでなく、発現制御機構も 明らかではない。当研究では子宮体癌における GPR54 の発現制御機構について検討し、メタスチ ン-GPR54 系が実際に浸潤・転移に寄与寸るかを解明することを目的とした。

子宮体癌 92 症例の臨床病理学的検討では、GPR54 は高分化型類内膜腺癌で有意に高く発現して いた。また、GPR54 を高度に発現している症例の予後は有意に良好であり、GPR54 の発現は既 知の予後因子である臨床進行期分類、組織型、深部筋層浸潤と相関していた。そこで、GPR54 が 子宮体癌の浸潤に果た寸役割を in vitro で検討したところ、GPR54 を発現する子宮体癌細胞株 Ishikawa や KLE では metastin-10 やFTM080 を添加することにより細胞遊走能、浸潤能は抑制 された。siRNA 法を用いて GPR54 の発現を knockdown した場合には metastin-10 の浸潤抑制効 果は認められなかったことより、メタスチンはGPR54を介して子宮体癌細胞の浸潤を抑制してい ることが示された。さらにCD1 Foxn1n マウスを用いた子宮体癌リンパ節転移モデル実験におい て、metastin-10 腹腔内投与は GPR54 を発現する子宮体癌の傍大動脈リンパ転移を有意に抑制し た。また、メチル化特異的 PCR を用いて GPR54 遺伝子のメチル化状態を解析したところ、GPR54 の発現の有無にはメチル化が関与しており、子宮体癌における GPR54 の発現はエピジェネティッ クに制御されていることが判明した。さに GPR54 の発現が抑制されている細胞株 HEC1A でも DNA 脱メチル化剂である 5-aza-DC を用いて GPR54 遺伝子を脱メチル化することによりメタス チンの効果が回復した。

本研究の結果から、メタスチンーGPR54 経路は、臨床的にも予後良好因子であることが示され た。メタスチンは GPR54 依存性に浸潤を抑制し、さらに GPR54 陰性株に対しても、GPR54 の 発現抑制を解除することにより浸潤抑制効果が得られた。以上のことから GPR54 の発現が低く予 後不良の子宮体癌に対してもメタスチンによる転移抑制治療の可能性が示唆された。
（論文審査の結果の要旨）

本研究は、子宮体癌の浸潤や転移に関わる因子の同定・臨床応用が子宮体癌の予後向上のために は不可欠と考光、転移抑制因子 Metastin の子宮体癌における役割とその治療応用の可能性に関し て基碟検討したものである。

京都大学にて初回治療を行った子宮体癌患者 92 例の臨床病理学的検討では、GPR54 の発現は早 期癌、高分化型の子宮体癌で高く、臨床的に予後良好因子であることが示された。また筋層浸潤の 程度やリンパ節転移の有無とは逆相関していた。GPR54 陽性の Ishikawa 細胞や KLE 細胞におい て、Metastin-10 は GPR54 を介して細胞遊走や浸潤を抑制した。また、GPR54 陽性の Ishikawa 細胞を用いた in vivo の検討では、Metastin-10 はマウスの子宮の移植腫場巣からリン八゚節への転 移も抑制した。一方 GPR54 陰性の HEC1A 細胞やAN3CA 細胞において、脱メチル化剂を用いて GPR54 の発現を誘導すると、Metastin-10 添加により細胞浸潤は抑制された。すなわち、GPR54 陰性の低分化な子宮体癌においても、脱メチル化剤などの併用により、その発現誘導が可能ならば、 Metastin-10 の転移抑制効果が得られる可能性も示された。

以上の研究は、子宮体癌における転移抑制経路の重要性と今後の転移抑制治療の有效性の解明に 貢献し、婦人科腫瘍学の進歩に寄与寸るところが多い。したがって、本論文は博士（医学）の学位 論文として価值あるものとみとめる。

なお、本学位授与申請者は、平成 23 年 4 月 12 日実施の論文内容とそれに関連した試問を受け、 合格と認められたものである。 